\title{
Not Only Survival but Stronger: The Impact of Alarming Invader of SARS-CoV-2 on Global Education
}

\author{
Xiaoqiao Cheng, ${ }^{1}$ Marta Pellegrini, ${ }^{2}$ Longjun Zhou, ${ }^{3,4}$ \\ Alan C.K. Cheung ${ }^{5}$
}

1. Nanjing Normal University, Nanjing 210097, Jiangsu, China

2. University of Florence, Via Laura, 48, 50121 Firenze FI, Italy

3. Jiangsu Second Normal University, Nanjing 211200, Jiangsu, China

4. Engineering Research Center of Digital Learning Support Technology, Ministry of Education, Changchun 130000, Jilin, China

5. The Chinese University of Hong Kong, Hong Kong, China

\begin{abstract}
The pandemic of Coronavirus disease 2019 (COVID-19) has caused an immeasurable impact on most countries and regions globally, especially in education. The shutdown of schools and classes in most countries and regions from pandemic has greatly affected education in the fight against COVID-19. The implementation of large-scale online education has also exposed global education's status quo and psychological and social problems. Based on the review of related studies, this paper analyzes the impact of the COVID-19 pandemic on education to further think about educational reform's direction and path.
\end{abstract}

Sci Insigt Edu Front 2020; 7(2):835-860.

Doi: 10.15354/sief.20.or061

How to Cite: Cheng, X., Pellegrini, M., Zhou, L. \& Cheung, A.C.K. (2020). Not only survival but stronger: The impact of alarming invader of SARS-CoV-2 on global education. Science Insights Education Frontiers, 7(2):835-860.

Keywords: COVID-19 Pandemic; Global Education; School Education; Online Education; Educational Information Technology

About the Authors: Xiaoqiao Cheng, School of Institute of Education Science, Nanjing Normal University, Nanjing 210097, Jiangsu, China. Email: xqcheng2008@vip.163.com. 


\section{Introduction}

7 HE outbreak of Coronavirus disease 2019 (COVID-19) at the end of 2019 spread to all parts of the world at an unprecedented speed, becoming the first global pandemic in more than 100 years, causing severe harm and threat to human lives (WTO, 2020). However, the pandemic's impact has far surpassed the medical and health fields, and the impact and destruction on the economy, politics, culture, education, and ideology are even more incalculable.

Education is one of the areas most affected by COVID-19 pandemic. With the spread of the pandemic, most countries and regions worldwide have temporarily shut down schools and other educational institutions to curb the spread of COVID-19. According to the "Education Policy Briefing during and after SARS-CoV-2 Pandemic" released by the United Nations in August 2020, the COVID-19 pandemic has caused the most severe damage to the education system in history. It has affected more than 191 countries and regions worldwide to close schools and educational institutions, and $94 \%$ of school students worldwide have been affected. In low-income and low-middleincome countries, this proportion is as high as 99\% (United Nations, 2020).

While this sudden pandemic has triggered a global education crisis, it has also forced governments, schools, and teachers of all countries to take the initiative to intensify educational reforms. Many countries and regions have accumulated much valuable experience in school management and system innovation, teaching methods and content innovation, teacher education, etc., which have become the basis for responding to the COVID-19 pandemic and further educational reform and development in the future. Based on reviewing related studies, this paper summarizes the educational problems exposed in the pandemic, discusses the educational development during the pandemic, and then comprehensively analyzes the pandemic's impact on education, aiming to realize substantial educational reform and make it more vital than ever.

About the Authors: Marta Pellegrini, Department of Education, Languages, Intercultures, Literatures and Psy-
chology, University of Florence, Via Laura, 48, 50121 Firenze FI, Italy. Email: marta.pellegrini@ unifi.it.

Correspondence to: Longjun Zhou, Jiangsu Second Normal University, Nanjing 211200, Jiangsu, and Engineering Research Center of Digital Learning Support Technology, Ministry of Education, Changchun 130000, Jilin, China. Email:294437034@qq.com.

$O R$

Alan Cheung, Department Chairperson \& Professor, Department of Educational Administration and Policy, The Chinese University of Hong Kong, Hong Kong 999077, China. Email: alancheung@cuhk.edu.hk.

Funding: This study was supported by the Jiangsu University Philosophy and Social Science Research Major Project (Project approval \#: 2020SJZDA110).

Conflict of Interests: None.

(C) 2020 Insights Publisher. All rights reserved.

Creative Commons Non Commercial CC BY-NC: This article is distributed under the terms of the Creative Commons Attribution-NonCommercial 4.0 License (http://www.creativecommons.org/licenses/by$\mathrm{nc} / 4.0 /$ ) which permits non-commercial use, reproduction and distribution of the work without further permission provided the original work is attributed by the Insights Publisher. 


\section{COVID-19 Pandemic Has Wreaked Havoc on the Global Education System}

The COVID-19 pandemic has caused education disruptions in most countries and regions around the world. At the peak of the pandemic in April, according to the official website of UNESCO, the governments of 113 countries/regions around the world have announced or implemented measures to close educational institutions to slow the pandemic's global spread. Among them, 102 countries have implemented national school suspensions, which have caused nearly 1.6 billion children and young people worldwide to be unable to continue their studies in schools. Also, 11 countries have implemented partial suspension policies; if these suspension policies are implemented nationwide, tens of millions of students will be affected by education disruption (UNESCO, 2020A). According to UNESCO, the disruption has affected the education system at all levels, from pre-school education to higher education, and the impact has far exceeded the scope of school closures (UNESCO, 2020B). In the "Education and COVID-19 Policy Brief" released on the 4th, UN Secretary-General Guterres stated that COVID-19 had caused the most significant damage to history's education system (António Guterres, 2020).

\section{Global Education Quality and Students' Academic Per- formance Decline}

In Hattie's comprehensive report of more than 800 meta-analyses on academic achievement, the relationship between learning time and academic achievement is analyzed, and it is found that the time invested in learning tasks is directly proportional to the learning achievement (Hattie, 2015). Affected by the pandemic, education was interrupted for up to five months, and students' time in their studies was forced to shorten. Nearly 7 million elementary and middle school students are forced to drop out (The World Bank, 2020). This will inevitably affect the global education and learning level.

\section{The Learning Time for Youths Has Been Shortened}

The ILO's report on the impact of the pandemic on young people released on August 11, "Youth \& COVID-19: Impacts on jobs, education, rights, and mental well-being," stated that since the beginning of the COVID-19 pandemic, globally, more than $70 \%$ of young people who are going to school or integrating industry and academia have been adversely affected by COVID-19 pandemic, and 65\% of young people said that the length of their studies has decreased since pandemic occurred. The report also showed that most young people's learning shifted from offline to online and remote during the 
pandemic period. Half of them believed that their studies would be delayed, and $9 \%$ believed that their studies might be abandoned halfway (IOL, 2020).

In the report of Azevedo and Hasan et al. (2020), students worldwide' significant study time is predicted based on the shortening of school time. The report stated that students completed an average of 11.2 years of schooling before the crisis during the entire school age. Considering learning quality, a primary education's practical education period of young students is 7.9 years. However, due to the occurrence of COVID-19, school closures for 5-6 months will cause students to immediately lose 0.6 years of school education, thereby reducing the sufficient period of children's primary education from 7.9 years to 7.3 years.

\section{The Quality of Students' Studies Has Declined.}

With the shortening of learning time and the transformation of learning methods, the quality of students' academic work will inevitably change accordingly. Especially in the home study stage, the difference in students' autonomous learning ability will have a crucial effect on learning quality. Students with low self-control ability will have worse learning effects after returning to school and accepting regular classroom teaching (Xiao \& Li, 2020).

In the study of Sintema (2020), students' academic performance in a public high school in Chipata District, Eastern Province of the Republic of Zambia, was investigated. According to the study, due to the reduction in Zambian middle school students' school time and the lack of e-learning facilities or lower levels of information, students' pass rate may decline if the Zambian Examination Board does not postpone the national examination date.

Fordjou et al. (2020) used quantitative research methods to investigate 214 students in the second and tertiary institutions in Ghana, West Africa. The survey results showed that due to the COVID-19 pandemic, students had encountered some challenges when they leave school to study, such as the online learning system's ineffectiveness and students' low ability to learn independently. Even most Ghanaian students could not access the Internet and lack relevant technical knowledge, and the e-learning platform launched thereby posed a challenge to most students, and the quality of students' learning during the COVID-19 pandemic had declined.

China was the first region to implement "School is Out, But Class is On," and the survey results on student performance during home study further confirmed this point. Dai \& Xia (2020) and Xie (2020) studied the learning effects of students during the pandemic period from the perspectives of online education and independent learning; it was concluded that whether it is online learning on the platform or under the guidance of teachers, autonomous learning had a specific effect on students' learning. However, compared with the prior pandemic level, students' academic performance has a more obvious decline. 


\section{The Student's Mental and Physical Health was Im- paired}

Full-time school education not only provides courses for students, but it is also the beginning of the student's understanding and contact with society, and its social nature cannot be ignored. Prolonged school closures meant that interactions between students and peers and students and teachers were interrupted. There is evidence that when children are out of school (such as weekends and summer vacations), their physical activity is weaker; they sit for more extended periods, eat and sleep irregularly, which leads to weight gain and loss of cardiorespiratory fitness (Brazendale et al., 2017; Wang et al., 2019). If children are confined to homes without outdoor activities and interaction with friends of the same age during the outbreak, the adverse health effects may be more serious.

Compared with the damage to physical health, the mental health of adolescents may be more easily overlooked. After all kinds of disasters occur, they will affect their mental health, and some may even cause long-term developmental damage. In severe cases, they may cause Acute Stress Disorder (ASD) and Post-traumatic Stress Disorder (PTSD) (Veenema \& Schroeder-Bruce, 2002), as well as a series of other reactions, including grief, depression, sleep disorders, and other health effects, as well as some unusual reactions of children such as deliberate tantrums and increased attachment (Madrid et al. 2006). Especially under the influence of COVID-19, teenagers have been in a state of family confinement for a long time, lack face-to-face contact with classmates, friends, and teachers, and the stress lasts for a long time, which may have a more lasting negative impact on them (Wang et al. al. 2020).

Wang \& Hegde et al. (2020) conducted interviews with 195 students from a large public university in the United States to understand the impact of the epidemic on their mental health and well-being. The survey results showed that the COVID-19 pandemic has a considerable negative impact on various academic, health, and lifestylerelated results. In particular, the COVID-19 outbreak has increased stress and anxiety, including fears and worries about oneself and loved ones' health.

A similar study (Orgilés et al., 2020) conducted in Spain and Italy examined how the COVID-19 outbreak affected children's well-being based on a survey completed by 1,143 parents of children aged 3 to 18 years. Compared to before the lockdown, a large percentage of parents $(85.7 \%)$ perceived changes in emotions and behaviors of their children, especially difficulties in concentration $(76.6 \%)$ and boredom $(52 \%)$. About a third of the sample reported that their children during the home confinement were more irritable $(39 \%)$, restless $(38.8 \%)$, and nervous $(38 \%)$, and felt loneliness $(31.3 \%)$ and uneasiness $(30.4 \%)$.

Besides, the reduced social interaction due to physical alienation has also become one reason college students feel stress and anxiety. This conclusion appears not only in the United States but also in previous surveys conducted in Spain, China, Nige- 
ria, and other countries (Gonzáleza et al., 2020; Quan, 2020; Rakhmanov \& Dane, 2020).

\section{Exacerbated the Inequities of Global Education}

Due to schools, universities, and training centers' closure, students' learning, especially education in low areas, faces tremendous challenges. The ILO's August 11 Communiqué also explained the increasing phenomenon of global education inequity. They believed that $65 \%$ of young people in high-income countries are eligible to receive video teaching, while only $18 \%$ of young people in low-income countries could learn online for a long time. Therefore, compared with middle- and high-income areas and families, the pandemic had a more severe impact on youth education in low-income countries (IOL, 2020).

The World Bank report also pointed out that before the COVID-19 pandemic outbreak, the world was already struggling with the in-depth learning crisis. $53 \%$ of children in low- and middle-income countries could not read and understand simple texts before the age of 10 (The World Bank, 2019). With the spread of the pandemic, prolonged suspension of education will prevent students from implementing a significant learning process and lead to the reversal of learning outcomes. This will produce more severe educational inequities, especially for those students who have special/diversified educational needs due to their qualifications, family financial level, etc. Such groups may not be able to deal with distance learning strategies or obtain useful information effectively. Therefore, countries will face more challenging issues, including educational inequity (The World Bank, 2020).

The World Bank also stated that dropouts and loss of family livelihoods caused by the COVID-19 pandemic might make girls particularly vulnerable and exacerbate exclusion and inequality, especially for the disabled and other marginalized groups.

\section{Pandemic Affects the Mobility of Global Education}

In addition to the impact on primary education, the pandemic has caused unprecedented large-scale disruptions in global education flows. Many schools said that even if pandemic tends to ease, they still decide to continue to teach online after school starts for safety reasons. For example, the University of Cambridge in the United Kingdom announced that all massive public courses in the 2020-2021 academic year would be changed online. The California State University system will continue online teaching in the fall semester of 2020, and the campus will remain closed (Tu, 2020). The pandemic's comeback or the new virus's mutation may block open communication in traditional space and time at any time. 


\section{Have an Impact on the Academic Performance of Inter- national Students}

Data from the Organization for Economic Cooperation and Development (OECD) showed that the number of international students studying in higher education worldwide had increased substantially in the past few decades, from 2 million in 1998 to 5.3 million in 2017 (OECD, 2020). Among them, UNESCO's data showed that 2.5 million people study outside their home countries. These large groups of overseas students could not return to campus on time due to travel restrictions imposed by many governments in 2020, or they have to leave campus during the closure of universities and colleges. Although many institutions provide online courses for students, students who participate in online learning still evaluate and certifiable learning results.

\section{It Hinders Academic Exchanges between Countries in the World}

The COVID-19 pandemic has the most significant impact on the academic community, and many studies on non-COVID-related topics have been put on hold. In the United Kingdom, the National Institute for Health Research Funding has stopped all nonCOVID research from bringing clinically trained personnel who are usually academically seconded back to the front line (National Institute for Health Research, 2020). In the United States, the National Institutes of Health has taken similar actions to close all non-critical research to free up personnel and resources for "critical" research (National Institutes of Health (NIH), 2020). In addition to health care research, Harvard University closed research in fields such as the humanities and social sciences and closed all laboratories in the School of Arts and Sciences (Harvard University, 2020).

Scholars have also raised concerns about the number of canceled or postponed scientific conferences (Impey, 2020). Cranford, Editor-in-Chief of Matter magazine, said that starting from March this year, the planned APS March Meeting and American Chemical Society (ACS) meetings were initially canceled or delayed (Cranford, 2020). These conferences are the key to scientific research in many disciplines. They can disseminate research results and provide networking opportunities for collaboration and job hunting. Many conferences have been conducted online, but these "virtual conferences" are usually unsuitable for networked and informal means of scientific communication.

\section{Have a Huge Impact on Education and Training Insti- tutions}


As one of the supplements to school education, shadow education has always occupied an important position in education, and it has been expanded globally in recent years (Berei \& Liao, 2012). In a study on the use of shadow education globally, Byun et al. (2018) proposed that about one-third of 15-year-old students from 64 countries/regions use shadow education.

However, this situation has changed dramatically after the COVID-19 pandemic. According to a 2020 survey report on the status of the global off-campus training and education industry during the pandemic period by the Training and Education Professional Committee of the China Private Education Association, the results show that over $90 \%$ of the institutions said that there was a significant impact on the pandemic. There are some or severe difficulties in the operation of the organization. Among them, $29 \%$ of institutions said that they had "severe impact" and that their operations were facing severe difficulties and might go bankrupt; $36.6 \%$ of institutions said that they had "a great impact" and their operations were temporarily stagnant; $25.4 \%$ of institutions said that the impact was enormous and their operations had some difficulties. In a barely maintained state, $7.9 \%$ of the institutions said they had a "small impact," and their operations remained stable despite difficulties. Only $1 \%$ of institutions stated that pandemic has no noticeable impact on business activities (China Private Education Association Training and Education Professional Committee, 2020).

It is not difficult to find that the current education and training industry is mostly offline training, and offline training institutions mostly use the offline small class teaching mode, which will inevitably involve more personnel gathering. When a pandemic is not fully controlled, and protective materials are insufficient, offline education and training institutions are under pressure. At the same time, offline education resources mostly came from tutors and contracted teachers. Therefore, pandemic impacts the traditional business model, and companies need to bear the rent, teacher fees, and courses that violate the agreement.

During this period, some companies began to make online transformation attempts, using cloud video conferencing to conduct small-scale online teaching or try to live teaching and other forms. To a certain extent, promote the online transformation of training institutions and provide digital power for small and medium training institutions. However, in the real environment, many offline training institutions lack complete equipment or sufficient financial support. Online transformation is facing huge problems, and it needs to face the market competition of large online training institutions. They lack the technology and relatively skilled operation ability, and online mode attempts are a big challenge for training institutions.

\section{COVID-19 Pandemic Has Given Birth to New Chang- es in Education and Teaching}

When facing the destruction that pandemic brought to education, we also saw the other side of its impact. To better respond to the education crisis, governments of countries 
have strengthened the education system's resilience and strengthened risk management capabilities by vigorously emphasizing equity and tolerance. This is the pandemic that gave birth to new changes in education and teaching. It will make global education stronger in dealing with Isudden crises.

\section{Form a New Understanding of Education}

The core goal of modern education has always been to "teach all knowledge to all people, "and the goal of knowledge-based teaching is to allow students to "learn" knowledge and skills (Li, 2015). With the integration of technology and education, students' ways to acquire knowledge have become more diverse. Schools are no longer like classrooms defined as imparting knowledge to students in the traditional concept, but more to teach students to think independently. Cultivate students' global vision and social responsibility in school education, and promote students' proper all-round growth. This pandemic helped people redefine school education goals and tasks, powerfully interpreted what kind of people to train, and established correct educational values.

During the pandemic period, the school and the family, teachers, and students are passively separated in space. While online education breaks the time and space limitations of traditional education, it also leads to some inevitable shortcomings of its own. The most important one is that online education has higher requirements for students' autonomous learning ability due to lack of supervision. In a report on online teaching research in China, in response to students' online learning problems, $37.1 \%$ of the 33,240 survey respondents believed that they were less active in online learning, while $45.8 \%$ of students said they need the supervision of teachers and parents to complete the task of online learning (Wang et al., 2020).

Online education has forced schools and teachers to pay more attention to students' learning while imparting knowledge. Teachers become learning guides and advisers, and students must master how to learn independently. When students return to campus again and school education restarts, we must further reflect on the nature of future teaching goals. We should gradually clear that the achievement of the goal of "mastering" knowledge is only the basis of future teaching, and higher-level teaching goals are to teach students the method of "learning" and the motivation for "active learning" (Rapanta et al., 2020 ). School education should focus on knowledge and focus on developing students' abilities, emotions, and character and focus on the cultivation of students' core qualities. Teachers should always guide students to summarize and share learning experiences, gains, and experiences, to enhance students' awareness of self-learning management and form active learning habits.

\section{Further, Improve and Perfect the Teaching Contents}

The primary basis for judging whether the content of education is proper is to see whether it prepares for a complete and satisfying life. Thus, Spencer (1884) ranked the 
importance of knowledge in life and ranked first as the knowledge that directly contributes to self-preservation and knowledge that can indirectly contribute to selfpreservation by obtaining life necessities. In school education, we pay more attention to subject knowledge while ignoring the knowledge people should have in life and development. For this reason, after the pandemic broke out, schools have reorganized their teaching content with life as the core, constructing life-oriented education content, and teaching students the life skills they need in the future.

\section{Increase the Content of Health and Life Education}

COVID-19 poses a severe threat to people's lives and health. According to the data from WHO presented on October 28, 2020, the pandemic has caused more than 1.16 million deaths (World Health Organization, 2020). The significance of life education is to help students gain knowledge of life and cultivate students' attitudes towards life. Education should see the value and meaning of life and teach students to face death, respect life, and value health.

In recent years, certain developments have been made in life education. More people have seen that death education will be closely related to history, Art, biology, philosophy, health education, war, genocide, life cycle, and biodiversity loss (Wass, 2004). However, most countries and regions do not include life education in their curriculum plans or endow them with any educational value (Herrán et al., 2019).

Due to the deaths caused by COVID-19, adding life education to school, curricula have become an urgent task for schools. Due to the high proportion of COVID-19 cases and deaths in the United States, more schools recommend that death education be included in school curricula (McAfee et al., 2020; Rodríguez et al., 2020).

Besides, courses to increase health knowledge about pandemic prevention have become one of the hard works of schools after the pandemic. Cahapay (2020) believes that in the later stage of pandemic normalization, schools need to specify disaster preparedness (disaster recovery) goals, especially in higher education, to expand the role of health maintenance in responding to global infectious disease outbreaks (Corless et al., 2018).

Now, almost all governments and education departments provide students with guidance on epidemic prevention and take appropriate measures to avoid infection or deal with it after infection. Health education, especially education-related to sudden disasters, will become an integral part of school curricula in the future.

\section{Pay More Attention to the Improvement of Students' In- formation Literacy}

Before the COVID-19 pandemic, "digital school" has been a concern for education in all countries. In the research of Iivari et al. (2020), the digital divide is raised to the basis for students' younger generation's survival and development. They believe that the 
school plays a pivotal role in empowering the younger generation of students to actively create and shape digital technologies, accept extensive digital transformation, and satisfy the younger generation and their digital future. However, the school's existing resources and abilities, including technologies, culture, practice, skills, and abilities, as well as their values, attitudes, identities, and mentality, are considered barriers to digital transformation (Vial, 2019), and there are fewer in school education Emphasize the improvement of students' information literacy as a basic curriculum. For example, the 2018 International Computer and Information Literacy Research Report (ICITS) (Fraillon et al. 2019) and surveys conducted in other European countries (Autorengruppe Bildungsberichterstattung 2020; Carlsson, 2019) showed that in European countries (such as Germany and Switzerland), the implementation and development of information and primary cation technology (ICT) in many schools lag behind people's expectations of the education system. Teachers, students, and families may not be fully proficient in applying digital learning tools to live. Therefore, the occurrence of COVID-19 pandemic may not only force school education to be interrupted but also a situation where students' digital ability affects the learning effect (König et al., 2020)is context, in July 2020, in the video conference on China's education informatization work, the Chinese government puts the improvement of education informatization literacy as a top priority. The meeting pointed out that nanotechnology, virtual reality, and artificial intelligence constitutes the future world. The "uncertainty" and "variable" of the future exist all the time. Facing the future of the information revolution, continuous improvement of students' information literacy is a sufficient guarantee for promoting student development and realizing education equity (Ministry of Education of the People's Republic of China, 2020a).

\section{Subvert the Normal Paradigm of Education}

Digitalization as a new technology to reform education, "survival of the fittest" manifests Darwin's theory in the education system. Naqvi \& Art (2020) bluntly stated that digitalization is an essential step in education reform, which will reshape the entire education system in the future.

After the pandemic occurred, all regions and countries are organizing schools to conduct online teaching. The school organization is facing profound changes. The teaching method has been changed from offline to online. Education has achieved the most massive migration in history (Zhou et al., 2020), forming a new teaching method: blended teaching. The core of mixed teaching is how to make up for the shortcomings of the two teaching methods and online teaching and rationally and effectively combine the advantages of "Internet + education" with traditional classroom teaching. This paradigm has wholly overturned the standard paradigm of "class teaching" education and teaching, and the hybrid teaching paradigm based on online teaching "learning center" has gradually been widely accepted and recognized.

In the home learning stage, online learning is mainly presented in the following organizational forms: live broadcasting class, live broadcasting + online quality class + 
learning task list, learning task list + online quality class (or self-made micro-class), etc. In the specific implementation, most lower-graders adopt the latter two forms, publishing a learning task list, plus a few minutes of micro-class video, and students can learn independently to adapt to students, parents, and society. The "learning before teaching" model, which is highly popular in the real education ecology, is widely used in elementary schools with the weakest autonomy during online teaching. This includes the test of elementary students' self-control and the exploration of opportunities for educational reform.

Taking Daxie No. 2 Primary School in Ningbo City, Zhejiang Province, China, as an example, to ensure the effectiveness of online teaching, the school uses questionnaires and telephone inquiries to grasp the learning environment's learning status of each family. By holding regular class meetings and communicating directly with all students individually, the emotional connection between teachers and students is maintained, and students' learning and psychological confusion are relieved. According to the actual situation of students from different families, various forms of online social platforms such as WeChat, QQ, Dingding, telephone, text messages, etc. are used to realize teaching feedback and to do an excellent job of learning evaluation to ensure the effect of online learning (Xie \& Yang, 2020).

In Norway, Bubb \& Jones (2020) examined the experiences of 1,000 homeconfined students in a municipality in the Norwegian fjords. This specific municipality had invested heavily in technology, and before the home confinement period, all students were provided with a computer or a tablet. The survey results showed that a large percentage of children $(88 \%)$ and teachers (80\%) agreed or strongly agreed that they had become better users of digital tools during the lockdown. Furthermore, this municipality's school leaders stated they were willing to continue using online tools such as digital meetings with teachers and parents and digital tools for differentiation in teaching.

With the pandemic's normalization, the blended education mode will become the normal teaching mode for a long time. In this regard, many schools have also stated that they will pay more attention to online and offline integration and innovation even after classes' resumption. On the one hand, it is necessary to deepen the advanced teaching models and practices that have been formed before the pandemic; on the other hand, continue to make full use of the Internet to make up for the lack of classroom teachings, such as the single school education resources, independent learning and personalized learning needs cannot be met (Kong, 2020). The development trend of education is to realize the transition from actual blended teaching to seamlessly integrated education, from large-scale standardized education to meaningful, deep, and sustainable personalized education, and to construct a new paradigm of online and offline education.

\section{Pay Attention to the Psychological Education of Teach- ers and Students}


Studies have shown that long-term accumulated stress can cause long-term psychological distress and even trauma to some people (Boyraz \& Legros, 2020). Student growth is a process of change from immature to mature. Due to unsound physical and mental development, weak self-control ability, and frequent and changeable psychological fluctuations of students, their psychology is often in the "dangerous period" and "transitional period" (Buhler, 1999). Especially when faced with some stressful life events, it is easy to have bad psychological stress. A pandemic is a specific stressful life event. Several months of home-based epidemic prevention can cause various negative and unhealthy emotions on students easily; it is also prone to social disorders such as hostility and sensitive interpersonal relationships and somatization reactions such as paranoia and sleep disorders (Tang et al., 2020). In the face of online classes, some students are uncomfortable and may also lead to problematic behaviors such as weariness and avoidance (Irawan et al., 2020). These will seriously hinder students' healthy development, so paying attention to students' mental health education has become a key topic.

After the pandemic was effectively controlled in China, schools worldwide began to resume classes in April. School teachers and students resumed from online learning to campus learning. Once again, the learning environment changes have caused all teachers and students to encounter varying adaptation problems. In order to help teachers and students pay attention to their physical and mental health and adjust their emotions, the Ministry of Education of China and the National Health Commission have issued "Twenty Questions about Resuming Schools and Resuming Classes under Normalization of Pandemic Prevention and Control" (Ministry of Education of the People's Republic of China, 2020b). Therefore, in the form of government documents, schools must incorporate teachers' and students' mental health into one of the critical tasks of school education after the beginning of school to realize the orderly development of psychological counseling for teachers and students resumption of classes. In particular, pay attention to eight types of high-risk students affected by the pandemic, including students from key epidemic areas, family members or students who have suffered from COVID-19, children of front-line workers in the fight against the epidemic, students in graduating classes, and notable families (such as divorced families, single-parent families, low-income families, families with low parental relationships, etc.), students with poor parent-child relationships, etc., focus on and understand the current learning situation, emotional fluctuations and parent-child relationships of students (Chen \& Wan, 2020).

In the United States, the Metropolitan Educational Research Consortium (MERC) of the VCU School of Education reviewed the mental health support measures for students returning to campus during COVID-19 and provided links to educators' related resources in the report. This answers how to solve students and school staff's mental health needs after returning to campus in the current education (Naff et al., 2020).

It can be expected that paying attention to teachers and students' mental health will become a problem that education needs to face for a long time. These psychological problems and behaviors that may occur are caused by the pandemic's psychological 
impact on people and action constraints, and the source of stress is evident. Even with the improvement of the pandemic, students will show changeable characteristics as the environment changes. For example, after returning to school, some children may have social fears and a lack of concentration. It is also worth noting that home-based epidemic prevention may cause family psychological problems and affect student psychology. These psychological problems may affect students' life and study, so they need to be rectified and adjusted urgently.

\section{Pandemic Promotes Innovation in School Management}

\section{Focus on Family-School Cooperation}

School and family are indispensable subjects in the healthy growth of children. Constructing a harmonious family-school relationship and forming a cooperative education pattern is of great significance to students' development. During the pandemic period, home learning brought education back to the family, the family became a temporary school, and the parents became teaching assistants. Family education played a significant supporting role (Anzani et al., 2020). This is a comprehensive test of family education. It tested the family happiness index, tested the relationship between husband and wife and parent-child, tested the parents' ability to build a family, and made parents reexamine the responsibility of the "front-line teacher" (Deng, 2020).

In China, to meet students' learning and development needs, schools use homeschool cooperation to give full play to family education's critical role during the "School is Out, But Class is On" period. In this way, parents are guided to participate in online teaching activities actively and offline academic guidance, effectively promoting students' home learning and realizing their healthy and happy growth (Xia, 2020).

In Italy, parents' role during the school closure has been crucial, especially in primary schools where children have a low level of autonomy and self-control. During the three months of lockdown, home-schooling has fostered a closer relationship between teachers and parents, realizing a fruitful integration between school education and family education (Pellegrini \& Maltinti, 2020).

Some scholars have suggested that in the US, to effectively meet students and families' urgent needs when schools reopen, state and regional leaders should consider establishing and expanding community schools. In community schools, students and families participate as partners in the education process and receive extensive coordinated support and services (Maier et al., 2020).

The "three-in-one education" of school, family, and society is a generalization of modern education to students' study and life scenes. In regular education, families and schools are each responsible for students' family education and school education. The school's guidance on family education is relatively simple, focusing mainly on parents' feedback on students' learning. During the pandemic period, because students 
study at home, family education and school education are integrated into the family space, and family education and school education are passively integrated.

The strengthening of school education not only weakened family education but also weakened its interaction with school education. In the post-pandemic era, family education's importance will become more prominent, and parents' acceptance of family education concepts and methods will consciously increase. Parents will pay more attention to high-quality parent-child companionship, focus on cultivating children's reading ability, good daily behavior habits, focus on children's participation in housework, and focus on the impact of their own words and deeds and parenting methods on children. Parents will have more understanding, respect, and support for schools and teachers, the ideological barriers of home-school communication will be weakened, and the content of home-school co-education will be more prosperous.

\section{Pandemic Makes the School Management Model More Perfect}

The pandemic broke out in a large area within a short period left all schools at a loss regarding how to respond. To cope with this sudden disaster, all schools have stepped up their arrangements and prepared for online teaching. In this process, although there is no evidence-based on school leaders in the pandemic, some practical models have emerged that provide instructions and insights on how school leaders operate. As Alma Harris (2020) pointed out, leaders need to establish and maintain a collaborative culture, which involves using the Internet between people when facing challenges.

The Internet-based school management model continues to innovate and improve. In order to ensure the quality of online teaching and the effectiveness of student learning, some schools have established a "four-in-one" online teaching quality monitoring and guarantee system of "real-time data monitoring-secondary teaching supervision-educational work weekly report-online teaching competition" (Wang, 2020).

For most schools, the experience during the online teaching period has enabled the original management model of each school to be effectively supplemented and improved in the online teaching: modular management has changed from offline to online; administrative leaders have joined each class group, carry out contract management; administrative team members stay in each grade group to assist teachers in their work; establish grade groups, teaching and research groups, and class "education communities" (Lu \& Zhou, 2020).

\section{Pay More Attention to Teacher Education}

Teacher professional development is a crucial factor in ensuring the smooth progress of education and teaching. In this pandemic, the traditional classroom teaching environment has undergone significant changes, and the related teaching activities, teaching space, the process of teaching implementation, teaching methods, and additional tools 
used in teaching are all changing. This also means that the connotation of teachers' teaching ability also needs to be continuously extended and expanded. Online teaching requires the educator to master the relevant platform's basic knowledge and the ability to operate information technology. It is even more necessary for teachers to grasp the difference between online teaching and traditional offline teaching in terms of teaching requirements. Therefore, teachers' information literacy has become the key to the effect of online teaching (Ma et al., 2020).

Before this, the digitalization of education has become a hot topic for all age groups in different disciplines, and digital tools have been widely used in schools, but teachers, schools, and related management departments are not prepared to act as digital leaders and change agents ( Papagiannidis et al., 2020; Vial, 2019), which leaves schools and teachers at a loss as to how to respond effectively to this sudden pandemic.

In a survey report of 14,348 elementary and middle school teachers in four provinces across the country on online teaching conditions, teachers paid longer working hours than offline teaching, but the teaching effect was average and became the second big problem (Zheng \& Ye, 2020).

In Germany, a 2019 survey suggested that a high proportion of teachers were willing to integrate digital tools in their instruction. However, they expressed the need for more professional development related to technology (Rohleder, 2019). The experience of online teaching during the spring semester could serve - as suggested by Michael Schratz - as "the most effective professional development measure of the century" (Schratz, 2020 cited in Blume, 2020, p. 892).

In response to this phenomenon, schools have launched emergency teacher training. The training content mainly revolves around digital skills such as online teaching platforms and resource selection and how to use these additional tools to promote the teaching ability, of course, efficiency effectively.

A study by Dougiamas and Taylor (2000) showed that teachers will have a more direct and decisive influence on students' views when developing distance teaching, which means teachers will bear greater responsibility when carrying out online teaching. In the digital age, where networking and informationization are the norms during the pandemic period, higher and broader requirements have been placed on teachers' teaching ability and quality. It requires teachers to apply information technology effectively and integrate information methods into online classroom teaching correctly.

Therefore, the development of teachers needs to be guided by more professional continuing education. Other areas of professional development include: making and sharing videos, managing students in online courses; involving students in asynchronous and synchronous discussions; building a sense of community; creating ideas for increasing student online participation; and using hands-on activities online, etc. (Williams et al., 2020). 


\section{Pandemic Promotes the Accelerated Development of the Education Information Industry}

Education has carried out an unprecedented online practice globally to realize that education is uninterrupted even in the pandemic period. Use the integration of information technology and education to realize "School is Out, But Class is On." This worldwide Internet education action has accelerated the development of the education information industry.

\section{Online Education Users are Showing Explosive Growth}

As the first country to implement "School is Out, But Class is On," China has implemented online teaching in schools of all levels and types since February. The 265 million school students across China have generally turned to online courses, and user needs have been fully released. Because of the massive demand for online learning, the state united online education companies by publishing free courses, online and offline linkages, etc. The industry shows explosive growth. According to the 45th "Statistical Report on China's Internet Development Status" released by the China Internet Network Information Center (CNNIC) on April 28, as of March 2020, the number of online education users in China reached 423 million, an increase of 2.22 from the end of 2018 Billion, accounting for $46.8 \%$ of the total netizens (China Internet Information Center, 2020).

\section{The Recognition of Education Informatization Has Been Improved}

For a long time, classroom teaching informatization has been facing insufficient resource allocation and a lack of teachers' usage habits. However, this time pandemic unexpectedly gave teachers, parents, and students rare informatization education training, and the recognition of online education has been significantly improved.

As the main driving force of education informatization, relevant departments also saw the development opportunities brought by China's education informatization industry in this pandemic. At the CPPCC meeting in May 2020, there were more than 20 proposals related to online education, including suggestions for the establishment of a free national public education platform, including the construction of a dedicated education network in the national new infrastructure construction project, and accelerating the construction of "Internet + Basic education" public service system, etc. Therefore, accelerating education informatization and reducing the digital gap has become a critical measure to promote the equitable development and quality improvement of education. 
In Germany, the COVID-19 pandemic provides an opportunity for the informatization reform of its national education. Among them, the most important is the advancement of DigitalPakt Schule. This agreement is an important resolution initiated by the German Federal Government to promote elementary and middle education informatization in the past two years. It is also one of the six essential measures implemented by the Federal Ministry of Education to promote informatization for all. However, due to various factors, this resolution has not been implemented for a long time. Therefore, the outbreak of the COVID-19 pandemic undoubtedly helped the implementation of this plan. At the same time that the state's primary and secondary schools announced the suspension of classes in March 2020, the federal government immediately allocated 100 million euros in emergency funds in the name of advancing the DigitalPakt Schule to encourage elementary and middle schools to carry out online teaching to protect students' learning rights and teaching order. Although this is a far cry from the previous budget of 5.5 billion Euros, for most schools, it is like nectar. Simultaneously, the federal-state government has also realized the urgency of establishing a virtual teaching network and has begun to invest many construction funds. For example, the Berlin city government allocated 1 million Euros to create a virtualized Elearning Platform, providing local students with nearly 10,000 learning videos, subjectbased course resources, and online video teaching (Chen, 2020).

The online teaching experience during the pandemic has brought an excellent demonstration effect on society and schools. This has also allowed countries to continue to increase their attention and investment in digitization and informatization. The cooperation between enterprises and the government will substantially promote education's informatization, moving from the hardware to the interconnection, intercommunication, and sharing of educational resources on a larger scale.

\section{Perspective}

The global outbreak of the COVID-19 pandemic has had a massive impact on the economy, politics, culture, and education of countries worldwide, and education is precisely a complete manifestation of all aspects of the pandemic. The experience during the COVID-19 pandemic has once again proved to the world that even when human life and health are threatened, education is also one of the most critical areas needing urgent attention and solutions.

In the current situation of pandemic normalization, summarizing the pandemic's impact on education can help us re-examine education's actual situation. We can see that education has shown various deficiencies in this pandemic, such as the unfairness of education. This unfairness is not only the unfairness between educational resources and educational technology between poor and rich areas, but also the unfairness of the right to education between men and women within the region. In terms of teaching methods, we have also noticed that schools and society are not adapting to online teaching. These incompatibilities reflect the backwardness of education in technology, such as the poor educational information infrastructure, the lack of digital education 
resources, and the substandard digital literacy of teachers and students. Besides, teachers' and students' psychological trauma in this pandemic has also caused us to reflect on whether education should pay attention to the cultivation of spiritual self-repair ability and teaching and educating people (Kohrt et al., 2020)?

At the same time, we are also delighted to see the changes in education in this sudden pandemic. The most significant is the change in teaching methods. Online education has become a mainstream learning method. Even after returning to the classroom, technology and education still show a trend of interactive integration. In a middle school in Sichuan, China, after the pandemic, the use of information technology to open up all the data of online and offline education and learning, accurate records, academic analysis, and a complete knowledge map built on data will further play its role. In this way, the optimization of educational effects has been realized, the enthusiasm of school teachers and students has been further promoted, a positive cycle has been formed, and the in-depth integration of online and offline models has finally been implemented ( $\mathrm{Li}$, 2020).

A similar experience took place in Italy after school reopening in September. Numerous secondary schools started to use blended learning with combined in-person and online activities to provide all students with educational content (Ministry of Education of Italy, 2020). Online activities are planned by the class teachers using synchronous and asynchronous modes to ensure adequate education and interactions among students of the same class.

There are more and more schools like this around the world. They are using their high-quality educational resources to maximize their superior resources' radiation, enabling more regions, more schools, and more students to share better educational concepts and educational resources and jointly promote regional education development. This is also the real impact of the pandemic on education, that is, not only survive, but also become more robust.

This teaching method's change and popularity also show us that having digital literacy skills and technology in education is no longer an option but a necessary fact. It can be seen from the cases of different regions and schools that digitalization is becoming a new driving force in all aspects and links of educational development. In the online education actions during the pandemic period, digital-driven education innovations can be seen everywhere, and various integrations beyond disciplines, classrooms, and schools have become the general trend (Dwivedi et al., 2020). To this end, all education-related parts or personnel should learn to adapt and develop their digital literacy.

However, at the same time, in using digital technology to promote education development, we should also have a clear and rational understanding of the limitations of digital technology. Intelligent digital technology will help people learn more accurately and effectively in the field of "computability," but "education is not only about acquiring skills but also about respecting the values of life and human dignity" (UNESCO, 2019). Education in the intelligent digital age cannot fall into the pitfalls of technological; at the same time, it needs to transcend pure utilitarianism and return to the humanistic standpoint of using intelligent technology to promote the healthy, free, 
and all-round development of people and help people achieve a better life. Therefore, the educational informatization we pursue is the simple addition of technology and education and the realization of students' growth and development while taking into account the various requirements of school teaching conditions, teacher teaching habits, and the current educational environment. It is responsible for improving teaching quality and promoting educational equity, and promoting social development.

\section{References}

Anzani, D.R.A., Zaeni, I.A., Nuqul, F.L., \& Mualifah, M. (2020). Relationship between parents' education level and parental engagement in the pandemic period of Covid19. International Webinar Series-

Educational Revolution in Post Covid Era, 30-38.

http://conference.um.ac.id/index.php/ksdp/ar ticle/view/101

Autorengruppe Bildungsberichterstattung. (2020). Bildung in Deutschland 2020 [Education in Germany 2020]. Bielefeld: wbv. [German]

Azevedo, J.P., Hasan, A., Goldemberg, D., Iqbal, S.A., \& Geven, K. (2020). Simulating the potential impacts of COVID-19 school closures on schooling and learning outcomes: a set of global estimates. Policy Research Working Papers. 9284. DOI: https://doi.org/10.1596/1813-9450-9284

Berei, M., \& Liao, Q. (2012). The global expansion of "shadow education": The pros and cons of education equity, quality, and development. International and Comparative Education, 34(2):13-17. [Chinese]

https://kns.cnki.net/kcms/detail/detail.aspx?d bcode $=$ CJFD \&dbname $=$ CJFD2012\&filenam e=BJJY201202003\&v=IlddEfavlobRCjBfgb 7OHnxMYx2UVespGiliCBeVL7Nmn2kf9y mAUQFxmqoCT\%25mmd2FTi

Bildungsberichterstattung, A. (2012). Bildung in Deutschland 2012: Ein indikatorengestützter
Bericht mit einer Analyse zur kulturellen Bildung im Lebenslauf. Bielefeld. [German] DOI: https://doi.org/10.3278/6001820cw

Blume, C. (2020). German teachers' digital habitus and their pandemic pedagogy.

Postdigital Science and Education, 2(3):879905. DOI: https://doi.org/10.1007/s42438020-00174-9

Boyraz, G., \& Legros, D.N. (2020). Coronavirus disease (COVID-19) and traumatic stress: Probable risk factors and correlates of posttraumatic stress disorder. Journal of Loss and Trauma, 25(6-7):503-522. DOI: https://doi.org/10.1080/15325024.2020.1763 $\underline{556}$

Brazendale, K., Beets, M.W., Weaver, R.G. Pate, R.R., Turner-McGrievy, G.M., Kaczynski, A.T., Chandler, J.L., Bohnert, A., \& von Hippel, P.T. (2017). Understanding differences between summer vs. school obesogenic behaviors of children: the structured days hypothesis. The International Journal of Behavioral Nutrition and Physical Activity, 14(1):100. DOI: https://doi.org/10.1186/s12966-017-0555-2

Bubb, S., \& Jones, M.A. (2020). Learning from the COVID-19 home-schooling experience: Listening to pupils, parents/carers and teachers. Improving Schools, 23(3):209-222. DOI: https://doi.org/10.1177/1365480220958797

Buhler, C. (1999). From birth to maturity: An outline of the psychological development of 
the child (Vol. 5). Psychology Press. ISBN: 9780415209854.

Byun, S.Y., Chung, H.J. \& Baker, D.P. (2018), "Global patterns of the use of shadow education: Student, family, and national influences", Research in the Sociology of Education, Emerald Publishing Limited, 20:71-105. DOI: https://doi.org/10.1108/S1479353920180000020004

Cahapay, M.B. (2020). Rethinking education in the new normal post-COVID-19 era: A curriculum studies perspective. Aquademia, 4(2):ep20018. DOI: https://doi.org/10.29333/aquademia/8315

Carlsson, U. (2019). Understanding media and information literacy (MIL) in the digital Age: A question of democracy. https://www.researchgate.net/publication/33 6232821_Understanding_Media_and_Infor mation_Literacy_MIL_in_the_Digital_Age_ A_Question_of_Democracy

Chen, H.Y. (2020). Germany: The epidemic has forced digital teaching to accelerate. Shanghai Education, 2020(14):26-27. [Chinese] DOI:

https://doi.org/CNKI:SUN:SHJZ.0.2020-14$\underline{009}$

Chen, Y., \& Wan, J. (2020) "Sunshine" spreads the mind, health and promotes growth. At the beginning of the school, the education and sports system has taken multiple measures to strengthen students' mental health education. (2020-05-08) [2020-11-15] Zhejiang News, [Chinese] https://zj.zjol.com.cn/news.html?id=144342 0

China Internet Information Center. (2020). The 45th "Statistical Report on the Development of China's Internet". 04-28-2020: 3. [Chinese] http://www.cac.gov.cn/202004/27/c_1589535470378587.htm

China Private Education Association Training and Education Committee. (2020). Eighty percent of training institutions are greatly affected by the epidemic and hope that the burden reduction policy will be implemented: During the epidemic, the status of offcampus training and education industry survey. China Foreign Trade, (4):78-80. [Chinese]
https://kns.cnki.net/kcms/detail/detail.aspx?F ileName $=$ ZKWM202004032\&DbName $=$ CJ FQ2020

Corless, I.B., Nardi, D., Milstead, J.A., Larson, E., Nokes, K.M., Orsega, S., Kurth, A.E., Kirksey, K.M., \& Woith, W. (2018). Expanding nursing's role in responding to global pandemics. Nursing Outlook, 66(4):412-415. DOI: https://doi.org/10.1016/j.outlook.2018.06.00 3

Cranford, S. W. (2020). I may not have symptoms, but COVID-19 is a huge headache. Matter, 2(5):1068-1071. DOI: https://doi.org/10.1016/j.matt.2020.03.017

Dai, D., \& Xia, X. (2020). Whether the school self-developed e-learning platform is more conducive to learning during the COVID-19 pandemic? Best Evidence in Chinese Education, 5(1):569-580. DOI:

https://doi.org/10.15354/bece.20.ar030

de la Herrán Gascón, A., Herrero, P. R., \& de Miguel Yubero, V. (2019). ¿ Está la muerte en el currículo español?= Is death in the Spanish curriculum? Revista de Educación, 385: 201-226. [Spanish] DOI: https://doi.org/10.4438/1988-592X-RE2019-385-422

Deng, T. (2020). Where is the focus of education development in the post-epidemic era? China Education News, 06-17-2020. (5th edition): School Principal Weekly. [Chinese] http://www.jyb.cn/rmtzgjyb/202006/t202006 17_337394.html

Dougiamas, M., \& Taylor, P.C. (2000). Improving the effectiveness of tools for the internetbased education. Teaching and Learning Forum 2000: Flexible Futures in Tertiary Teaching Curtin University of Technology. https://researchrepository.murdoch.edu.au/id leprint/37770/

Dwivedi, Y.K., Hughes, D.L., Coombs, C., Constantiou, I., Duan, Y., Edwards, J.S., Gupta, B., Lal, B., Misra, S., Prashant, P., Raman, R., Rana, N.P., Sharma, S.K., \& Upadhyay, N. (2020). Impact of COVID-19 pandemic on information management research and practice: Transforming education, work and life. International Journal of Information Management, 55:102211. DOI: 
https://doi.org/10.1016/j.ijinfomgt.2020.102 211

Ferdig, R.E., Baumgartner, E., Hartshorne, R., Kaplan-Rakowski, R. \& Mouza, C. (2020). Teaching, technology, and teacher education during the COVID-19 pandemic: Stories from the field. Association for the Advancement of Computing in Education (AACE). Retrieved December 4, 2020 from https://www.learntechlib.org/p/216903/

Fraillon, J., Ainley, J., Schulz, W., Friedman, T., \& Duckworth, D. (2020). Preparing for Life in a Digital World: The IEA International Computer and Information Literacy Study 2018 International Report. New York:

Springer.

https://www.iea.nl/publications/studyreports/preparing-life-digital-world

Gonzalez, S.P., Gardiner, D., \& Bausch, J. (2020). Youth and COVID-19: impacts on jobs, education, rights and mental well-being: survey report 2020. ILO, Geneva, 05 Dec 2020

https://www.voced.edu.au/content/ngv:8770 $\underline{5}$

Guterres, A. (2020). Secretary-General's video message to launch Policy Brief on Education and COVID-19 (2020-08-04) [2020-11-02] https://www.un.org/sg/zh/content/sg/stateme nt/2020-08-04/secretary-generals-videomessage-launch-policy-brief-education-andcovid-19-scroll-down-for-french-version

Harvard University. (2020). Coronavirus (COVID-19): Keep Harvard Healthy. [Internet]. [Cited 2020 Mar 21].

https://www.harvard.edu/coronavirus

Hattie, J. (Ed.) (New Zealand). (2015) Zhengmei Peng et al. (Translated). Visible Learning: A synthesis of over 800 meta-analyses relating to achievement. Beijing: Educational Science Press, pp213-pp214.

Iivari, N., Sharma, S., \& Olkkonen, L.V. (2020). Digital transformation of everyday life How COVID-19 pandemic transformed the basic education of the young generation and why information management research should care? International Journal of Information Management, 55:1-6. DOI: https://doi.org/10.1016/j.ijinfomgt.2020.102 $\underline{183}$
Impey, C. (2020). Coronavirus: social distancing is delaying vital scientific research. [Internet]. The Conversation, [Cited 2020 Mar 21] http://theconversation.com/coronavirussocial-distancing-is-delaying-vital-scientificresearch-133689

Irawan, A., Dwisona, D., \& Lestari, M. (2020). Psychological impacts of students on online learning during the pandemic COVID-19. KONSELI: Jurnal Bimbingan dan Konseling (E-Journal), 7(1):53-60. DOI: https://doi.org/10.24042/kons.v7i1.6389

Kidd, W., \& Murray, J. (2020). The Covid-19 pandemic and its effects on teacher education in England: How teacher educators moved practicum learning online. European Journal of Teacher Education, 43(4):542558.

https://doi.org/10.1080/02607476.2020.1803 $\underline{050}$

Kohrt, B. A., Ottman, K., Panter-Brick, C., Konner, M., \& Patel, V. (2020). Why we heal: The evolution of psychological healing and implications for global mental health. Clinical Psychology Review, 82:101920. DOI: https://doi.org/10.1016/j.cpr.2020.101920

Kong, Z.G. (2020). Integration and innovation: the choice of online and offline teaching in the post-epidemic era. Digital Teaching in Primary and Secondary Schools, 2020(7):62-65. [Chinese] https://kns.cnki.net/kcms/detail/detail.aspx?d $\underline{\text { bcode }=\text { CJFD } \& \text { dbname }=\text { CJFDLASN2020\&f }}$ ilename $=Z$ SZJ202007017\&v=0Hlp410rzgOl RkbyBOa7470\%25mmd2BN8YYFdADvfa9 awKY9G5uxcC\%25mmd2FHpkAgOAthzvc $\underline{\text { AiYN }}$

König, J., Jäger-Biela, D. J., \& Glutsch, N. (2020). Adapting to online teaching during COVID-19 school closure: teacher education and teacher competence effects among early career teachers in Germany. European Journal of Teacher Education, 43(4): 608-622. DOI: https://doi.org/10.1080/02619768.2020.1809 $\underline{650}$

Li, J. (2015). On the teaching path of "Teach all knowledge to all people". Modern Educational Science, 2015(10):132-134. [Chinese] 
DOI: https://doi.org/cnki:sun:jlik.0.2015-10046

Li, Y. (2020). Analysis and enlightenment of user agreements based on the three smart teaching tools of rain classroom, Dingtalk live broadcast and Tencent classroom in the post-epidemic Era. Management Science and Engineering, 14(1):44-48. DOI:

http://dx.doi.org/10.3968/11904

Lu, H., \& Zhou, L. (2020). Epidemic prevention and teaching measures in Chinese elementary and middle schools under the background of COVID-19 pandemic. Science Insights Education Frontiers, 6(2):669-690. https://doi.org/10.15354/sief.20.or027

Ma, N., Zhang, Y. \& Du, L. (2020). The test and impact of large-scale online teaching on teacher information literacy during the epidemic. Shanghai Education, 2020(12):8-11. [Chinese]

https://kns.cnki.net/kcms/detail/detail.aspx?d bcode $=$ CJFD $\&$ dbname $=$ CJFDLASN2020\&f ilename $=$ SHJZ202012003\&v=uUgWn2qvUI yBP6athgN2rOWngRgipQ0tZFPMUYfPIC QtVB6DfDRCrtHgOml2Rs1W

Madrid, P.A., Grant, R., Reilly, M.J., \& Redlener, N.B. (2006). Challenges in meeting immediate emotional needs: Short-term impact of a major disaster on children's mental health: Building resiliency in the aftermath of Hurricane Katrina. Pediatrics, 117(5 Pt 3):S448-S453. DOI: https://doi.org/10.1542/peds.2006-0099U

Maier, A., Edgerton, A.K., \& Darling-Hammond, L. (2020). Restarting and Reinventing School: Learning in the Time of COVID and Beyond, Priority 8: Establish Community Schools and Wraparound Supports, 79-87. https://learningpolicyinstitute.org/sites/defau $\underline{\text { lt/files/product- }}$ files/Restart_Reinvent_Schools_COVID_Pri ority8_Community_Schools.pdf

McAfee, C. A., Jordan, T. R., Cegelka, D., Polavarapu, M., Wotring, A., WagnerGreene, V. R., \& Hamdan, Z. (2020). COVID-19 brings a new urgency for advance care planning: Implications of death education. Death Studies, 1-6. DOI: https://doi.org/10.1080/07481187.2020.1821 $\underline{262}$
Ministry of Education of Italy (2020). Guidelines for blended digital education. [Italian] https://www.miur.gov.it/documents/20182/0/ ALL.+A+_+Linee_Guida_DDI_pdf/f0eeb0 b4-bb7e-1d8e-4809a359a8a7512f?t=1596813131027

Ministry of Education of the People's Republic of China. (2020a). The 2020 National Education Informatization Work Conference is held [2020-07-15] (2020-10-31) nese ]http://www.moe.gov.cn/jyb_xwfb/gzdt _gzdt/moe_1485/202007/t20200715_472891 . html

Ministry of Education of the People's Republic of China. (2020b). Twenty questions about resuming school and class under the normalization of epidemic prevention and control. (2020- 06-16) [2020-11-15] [Chinese] http://www.gov.cn/fuwu/202006/16/content_5519760.htm

Naff, D., Williams, S., Furman, J., \& Lee, M. (2020). Supporting student mental health during and after COVID-19. Richmond, VA: Metropolitan Educational Research Consortium.

https://scholarscompass.vcu.edu/merc pubs/ $112 /$

Naqvi, W. M., \& Sahu, A. (2020). Paradigmatic shift in the education system in a time of COVID 19. Journal of Evolution of Medical and Dental Sciences, 9(27):1974-1976. DOI: https://doi.org/10.14260/jemds/2020/430

National Institutes of Health (NIH). (2020). NIH Shifts Non-mission-critical Laboratory Operations to Minimal Maintenance Phase. [Internet] [Cited 2020 Mar 21].

https://www.nih.gov/news-events/newsreleases/nih-shifts-non-mission-criticallaboratory-operations-minimal-maintenancephase

National lnstitute for Health Research. (2020). DHSC issues guidance on the impact of COVID-19 on research funded or supported by NIHR. [Internet]. [Cited 2020 Mar 21]. https://www.nihr.ac.uk/news/dhsc-issuesguidance-on-the-impact-on-COVID-19-onresearch-funded-or-supported-by-nihr/24469

Odriozola-González, P., Planchuelo-Gómez, Á., Irurtia, M.J., \& de Luis-García, R. (2020). Psychological effects of the COVID-19 out- 
break and lockdown among students and workers of a Spanish university. Psychiatry Research, 290:113108. DOI:

https://doi.org/10.1016/j.psychres.2020.1131 $\underline{08}$

OECD. (2020). Education at a Glance 2020: OECD Indicators (2020-09-08) [2020-11-02] https://www.oecd.org/education/educationat-a-glance/

Orgilés, M., Morales, A., Delvecchio, E., Mazzeschi, C., \& Espada, J.P. (2020, April 21). Immediate psychological effects of the COVID-19 quarantine in youth from Italy and Spain. PsyArXiv Preprints, DOI: https://doi.org/10.31234/osf.io/5bpfz

Owusu-Fordjour, C., Koomson, C.K., \& Hanson, D. (2020). The impact of COVID-19 on learning: The perspective of the Ghanaian student. European Journal of Education Studies, 7(3):88-101. DOI: http://dx.doi.org/10.46827/ejes.v0i0.3000

Pellegrini, M., \& Maltinti, C. (2020). 'School Never Stops': Measures and Experience in Italian Schools during the COVID-19 Lockdown. Best Evidence in Chinese Education, 5(2):649-663. DOI: https://doi.org/10.15354/bece.20.or021

Peng, W., Li, X., \& Fan, L. (2020). Research on Information-based Teaching and its Influence on Future Education under the Background of Epidemic Situation. 2020 IEEE 2nd International Conference on Computer Science and Educational Informatization (CSEI), Xinxiang, China, 2020, pp340pp343, DOI:

https://doi.org/10.1109/CSEI50228.2020.91 42530

Quan, L. (2020). Practical analysis of mental health assistance in elementary and middle schools under COVID-19 pandemic: A case study of City A in Jiangsu, China. Science Insights, 34(3):183-193. DOI: https://doi.org/10.15354/si.20.or026

Rakhmanov,O., \& Dane,S. (2020). Knowledge and anxiety levels of African university students against COVID-19 during the pandemic outbreak by an online survey. Journal of Research in Medical and Dental Science, 8(3):53-56. https://www.researchgate.net/publication/34 2391926

Rapanta, C., Botturi, L., Goodyear, P., Guàrdia, L., \& Koole, M. (2020). Online university teaching during and after the Covid-19 crisis: Refocusing teacher presence and learning activity. Postdigital Science and Education, 2(3):923-945. DOI: https://doi.org/10.1007/s42438-020-00155-y

Rodríguez, P., Herrán, A.D.L., \& Miguel, V.D. (2020). The inclusion of death in the curriculum of the Spanish Regions. Compare: $A$ Journal of Comparative and International Education, 2020:1-19. DOI: https://doi.org/10.1080/03057925.2020.1732 192

Rohleder, B. (2019). Smart School - Auf dem Weg zur digitalen Schule. Berlin: Bitkom Research GmbH [German] https://www.bitkom.org/sites/default/files/20 19-03/Pr\%C3\%A4sentation\%20BitkomPK\%20Bildungskonferenz\%2012.03.2019 f inal.pdf

Scheller, H. (2019). "Digitalpakt Schule". Föderale Kulturhoheit zulasten der Zukunftsfähigkeit des Bildungswesens? Aus Politik und Zeitgeschichte, 69(2728/2019):11-17. [German] https://www.bpb.de/apuz/293122/digitalpakt -schule-foederale-kulturhoheit-zulasten-derzukunftsfaehigkeit-des-bildungswesens

Schratz, M. (2020). Corona-Krise: Das verrückte Klassenzimmer. Der Standard. [German]

https://www.derstandard.at/story/200011625 0722/corona-krise-das-ver-rueckteklassenzimmer

Sintema, E.J. (2020). Effect of COVID-19 on the performance of grade 12 students: Implications for STEM education. Eurasia Journal of Mathematics, Science and Technology Education, 16(7):em1851. DOI: https://doi.org/10.29333/ejmste/7893

Song, S. Research on the application of researchbased learning to the cultivation of students' innovation ability in high school information technology teaching", Dissertation; Hebei Normal University, 2014. [Chinese] http://cdmd.cnki.com.cn/Article/CDMD10094-1014259460.htm 
Spencer, H. (1860). What knowledge is of most worth? In H. Spencer, Education: Intellectual, moral, and physical (pp21-pp96). D Appleton \& Company. DOI: https://doi.org/10.1037/12158-001

Tang, W., Hu, T., Hu, B., Jin, C., Wang, G., Xie, C., Chen, S., \& Xu, J. (2020). Prevalence and correlates of PTSD and depressive symptoms one month after the outbreak of the COVID-19 epidemic in a sample of home-quarantined Chinese university students. Journal of Affective Disorders, 274:17. DOI:

https://doi.org/10.1016/j.jad.2020.05.009

The World Bank. (2019). Learning poverty.

[2019-10-15][2020-10-19]

https://www.worldbank.org/en/topic/educati on/brief/learning-poverty

The World Bank. (2020). Guidance Note on Education Systems' Response to COVID-19. (2020-03-25) [2020-04-13]

http://pubdocs.worldbank.org/en/450881585 235950757/COVID19-Education-SectorGuidance-Note-March26.pdf

Tu, D.W. (2020). Challenges and Strategies Of Education Opening To The Outside World. China Education News. October 08, 2020 (7th edition). [Chinese] http://www.jyb.cn/rmtzgjyb/202010/t202010 08_363616.html

UNESCO (2015). Rethinking education. Towards a global common good? Paris: UNESCO. Retrieved October 28, 2015. http://unesdoc.unesco.org/images/0023/0023 25/232555e.pdf

UNESCO. (2020a). COVID-19: with half of world' s student population out of school, UNESCO launches coalition to accelerate remote learning solutions. (2020-0318)[2020-10-14].

https://en.unesco.org/news/covid-19-halfworlds-student-population-out-schoolunesco-launches-coalition-accelerate-remote

UNESCO. (2020b) Education: From response to recovery. (2020-05-25)[2020-10-14] [Chinese]

https://zh.unesco.org/themes/educationemergencies/coronavirus-school-closures

United Nations News. (2020) UN chief outlines 'bold steps' for education in the face of
COVID-19 disruption (2020-08-04)

https://news.un.org/en/story/2020/08/106944 $\underline{2}$

United Nations. (2020). Policy Brief: Education during COVID-19 and beyond. (2020-0804)[2020-08-14].

Veenema, T. G., \& Schroeder-Bruce, K. (2002). The aftermath of violence: children, disaster, and posttraumatic stress disorder. Journal of Pediatric Health Care: Official Publication of National Association of Pediatric Nurse Associates \& Practitioners, 16(5): 235-244. DOI:

https://doi.org/10.1067/mph.2002.126869

Vial, G. (2019). Understanding digital transformation: a review and a research agenda. The Journal of Strategic Information Systems, 28(2):118-144. DOI: https://doi.org/10.1016/j.jsis.2019.01.003

Wang, D., Wang, H., Zhang, W., Wang, H., \& Shen, X. (2020). Online teaching during the "School is Out, but Class is On" period: Based on 33,240 online questionnaire surveys across China. Best Evidence in Chinese Education, 6(1):753-767. DOI: https://doi.org/10.15354/bece.20.ar061

Wang, G., Zhang, J., Lam, S.P., et al. (2019). Ten-Year secular trends in sleep/wake patterns in Shanghai and Hong Kong schoolaged children: A tale of two cities. Journal of Clinical Sleep Medicine: JCSM: Official Publication of the American Academy of Sleep Medicine, 15(10):1495-1502. DOI: https://doi.org/10.5664/jcsm.7984

Wang, H. (2020). Effective ways of education and teaching management in colleges and universities. Yangtze River Series, 2020(27):98-99. [Chinese] https://kns.cnki.net/kcms/detail/detail.aspx?F $\underline{\text { ileName }=\text { CJCK202027061 \&DbName }=\text { CJF }}$ NTEMP

Wang, X., Hegde, S., Son, C., Keller, B., Smith, A., \& Sasangohar, F. (2020). Investigating mental health of US college students during the COVID-19 pandemic: Cross-sectional survey study. Journal of Medical Internet Research, 22(9):e22817. DOI: https://doi.org/10.2196/22817

Wass, H. (2004). A perspective on the current state of death education. Death Studies, 
28(4):289-308. DOI:

https://doi.org/10.1080/07481180490432315

WHO Director-General. (2020). WHO DirectorGeneral's opening remarks at the media briefing on COVID-19 (2020-03-11) [202007-10].

https://www.who.int/dg/speeches/detail/who -director-general-sopening-remarks-at-themedia-briefing-on-COVID-19---11-march$\underline{2020}$

World Health Organization. (2020). WHO Coronavirus Disease (COVID-19) Dashboard. [2020-10-28] (2020-10-29) https://covid19.who.int/

Xia, J. (2020). Practical exploration of schoolfamily cooperative education during the COVID-19 epidemic: A case study of Zhenjiang Experimental School in Jiangsu Province, China. Best Evidence in Chinese Education, 4(2):521-528. DOI:

https://doi.org/10.15354/bece.20.rp003

Xiao, C. \& Li, Y. (2020). Analysis on the Influence of the Epidemic on the Education in China. 2020 International Conference on Big Data and Informatization Education (ICBDIE), Zhangjiajie, China, 2020, 143-
147, DOI:

https://doi.org/10.1109/icbdie50010.2020.00 $\underline{040}$

Xie, Z. (2020). Effectiveness of autonomous learning materials for students during the COVID-19 pandemic: A Case study of the Daxie Second Elementary School in Ningbo, Zhejiang, China. Science Insights Education Frontiers, 6(1):613-624. DOI: https://doi.org/10.15354/sief.20.or023

Xie, Z., \& Yang, J. (2020). Autonomous learning of elementary students at home during the COVID-19 epidemic: A case study of the Second Elementary School in Daxie, Ningbo, Zhejiang Province, China. Best Evidence in Chinese Education, 4(2):535-541. DOI: https://doi.org/10.15354/bece.20.rp009

Zheng, D.H., \& Ye, S.N. (2020). "School is Out, But Class is On" online teaching survey: Based on data from the four provinces of Zhejiang, Jiangsu, Shandong, and Henan. Research in Educational Development, 2020(8):23-31. [Chinese] DOI: https://doi.org/10.14121/j.cnki.1008$\underline{3855.2020 .08 .006}$ 